\title{
First nest records, nestling growth and morphometrics of Dendroplex picus peruvianus (Aves: Dendrocolaptidae) in southwestern Brazilian Amazon
}

\author{
Primeros registros de nidos, crecimiento de polluelos y morfometría de Dendroplex picus \\ peruvianus (Aves: Dendrocolaptidae) en el suroeste de la Amazonía brasileña
}

\author{
Jônatas Lima * \\ https://orcid.org/0000-0002-9663-5208 \\ jonatasornito@gmail.com \\ Edson Guilherme \\ https://orcid.org/0000-0001-8322-1770 \\ guilherme.edson@gmail.com \\ * Corresponding author \\ Laboratório de Ornitologia, Centro de Ciências Bio- \\ lógicas e da Natureza, Universidade Federal do Acre, \\ Rio Branco, AC, Brazil.

\section{Citación} \\ Lima J, Guilherme E. 2021. First nest records, nestling \\ growth and morphometrics in Dendroplex \\ picus peruvianus (Aves: Dendrocolaptidae) \\ in southwestern Brazilian Amazon. Revista \\ peruana de biología 28(3): e 20476 (Agosto \\ 2021). doi: http://dx.doi.org/10.15381/rpb \\ v28i2.20476
}

\section{Presentado: $\quad$ 14/09/2020 \\ Aceptado: $\quad$ 26/04/2021 \\ Publicado online: $30 / 08 / 2021$}

Editor:

Leonardo Romero

\section{Resumen}

Reportamos los primeros datos sobre la anidación y desarrollo de Dendroplex picus peruvianus en un fragmento de bosque en el suroeste de la Amazonia. Observamos y capturamos esta especie entre 1999 y 2019. Encontramos dos nidos activos en 2012 y 2013, pero monitoreamos solo uno. El tamaño de la camada fue de dos huevos incubados durante 16 días. La tasa de crecimiento constante $(K)$ de los polluelos fue de 0.31 con una asíntota de crecimiento de $46.3 \mathrm{~g}$. Registramos una longevidad mínima de ocho años. Nuestros datos mostraron que $D$. $p$. peruvianus se reproduce principalmente en la temporada de lluvias (septiembre-marzo) superponiéndose con el periodo de cambio de pluma.

\section{Abstract}

We reported the first data on the breeding and growth in Dendroplex picus peruvianus from a forest fragment in southwestern Amazonia. We observed and netted this species between 1999 and 2019. We found two active nests in 2012 and 2013, but we monitored only one. Clutch size was two eggs, incubated for 16 days. The constant growth rate $(K)$ of nestlings was 0.31 with a growth asymptote of $46.3 \mathrm{~g}$. We recorded a longest minimum longevity of eight years. Our records showed that D. $p$. peruvianus breeds mainly in the rainy season (September-March) overlapping with the molt period.

\section{Palabras claves:}

Dendroplex picus peruvianus; Dendrocolaptidae; Aves neotropicales; reproducción; anidación; estacionalidad.

\section{Keywords:}

Dendroplex picus peruvianus; Dendrocolaptidae; Neotropical birds; reproduction; breeding; seasonality.

\section{Introduction}

The Straight-billed Woodcreeper Dendroplex picus ranges from Panama to northern South America (Marantz et al. 2020). Thirteen subspecies of D. picus are recognized (Marantz et al. 2020). The eastern extreme of the Brazilian state of Acre and adjacent areas of the lowlands of southeastern Peru and northeastern Bolivia represent the limit of the distribution of $D$. p. peruvianus in southwestern Amazon (Schulenberg et al. 2010, Guilherme 2016, Marantz et al. 2020). The Straight-billed Woodcreeper is typically found, in the state of Acre, in upland forests, along edges and in open areas, including anthropic clearings with palms, and urban areas. Records of reproduction in the Woodcreeper come mostly from Majewska and Oteyza (2013) in Venezuela, supplemented with some details from French Guiana (Ingels \& Giraud-Audine 2013) and northern Brazil (Oniki \& Willis 1983). Here we provide new records of breeding and nestling growth, the first in a subspecies of the Straight-billed Woodcreeper from the southwestern Brazilian Amazon. 


\section{Material and methods}

We studied the Woodcreeper in the Zoobotanical Park (ZP, $09^{\circ} 57^{\prime} 08.9^{\prime \prime}$ S, $67^{\circ} 52^{\prime} 22.5^{\prime \prime} \mathrm{W}$ ) of the Federal University of Acre, which includes a forest fragment ( $\sim 100$ ha) mostly surrounded by urban areas of the city of Rio Branco (Guilherme 2001, Souza et al. 2020). We measured (analogue callipers, $0.05 \mathrm{~mm}$ precision) and weighed (Pesola ${ }^{\circledR}$ scale, $1 \mathrm{~g}$ precision) eggs and nestlings every two days. The incubation period was the interval from the date the last egg was laid until the last egg hatched, based on nest 1 . The nestling period began at the first hatching and ended with fledging of the last nestling (day 0, see Oniki \& Willis 2001). We estimated growth following Ricklefs (1967) using the equation:

$$
W(t)=A /(1+e[-K(t-t i)]
$$

Where $\mathrm{W}(t)$ is the mass of the nestling at age $t, A$ is the asymptote of the growth curve, $K$ is the constant growth rate and $t i$ is the inflection point of the growth curve. We run the equation in the $\mathrm{R}$ software version 3.5.1 (R Core Team 2018).
We captured woodcreepers from 1999-2019 (in 60940.3 net/hours $)$ using $36 \mathrm{~mm}$ mesh nets $(12 \times 2.5$ $\mathrm{m}$ ) and banded all birds with numbered bands (CEMAVE, SNA no. 32465-4). All birds captured were measured only once at the time of first capture. During ringing, we distinguished adults and juveniles based on the presence of juvenile plumage (see Sibley 2010, Johnson et al. 2011). We examined each trapped individual to determine moult in the remiges and rectrices (Sibley 2010) and presence or absence of a brood patch (Redfern 2010), and we included only adults in the analysis. We calculated minimum longevity from the first day an individual was banded to their last recapture (Scholer et al. 2018).

\section{Results}

We found nests in open areas near the forest edge (December 2012, October 2013). Nest 1 was built in a broken trunk of a dead Bactris gasipaes palm (Fig. 1a). Nest 2 was built in the cavity of the trunk of a Samanea saman (Fabaceae) (Fig. 1b, c).
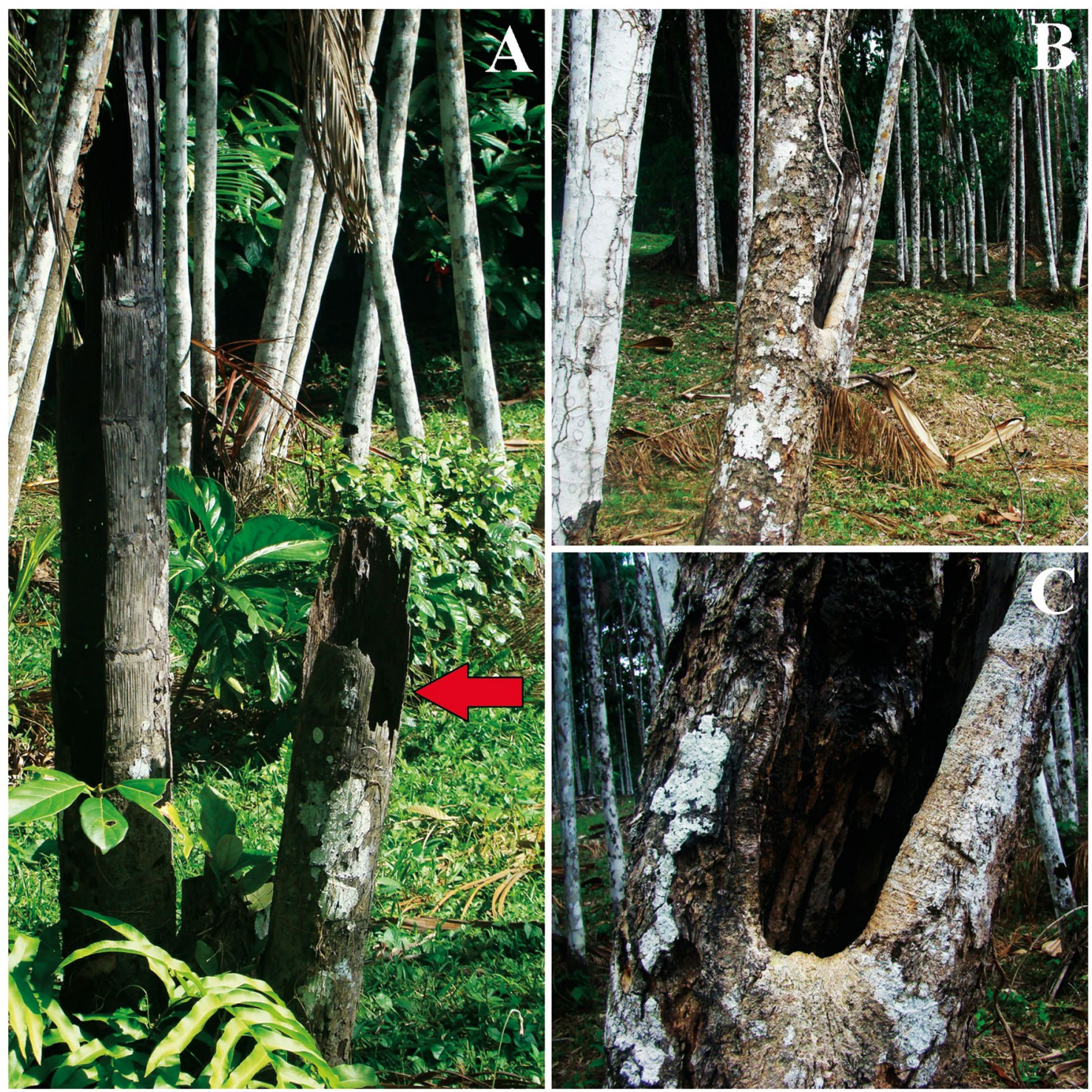

Figure 1. Active Dendroplex picus peruvianus nests in a forest fragment in southwestern Amazonia. (a) Detail of nest 1 (red arrow). (b) Nest 2 in trunk. (c) Detail of entrance of nest 2. 
Nest openings were 1.1 and $1.46 \mathrm{~m}$ above the ground. The chamber of nests contained pieces of tree bark (Fig. 2a). Measurements of nest 1 and nest 2 were: entrance diameter of trunk was 14.5 and $12 \mathrm{~cm}$ and incubation chamber until entrance was 57 and 39, respectively. Both nests had a clutch size of two eggs. In one nest, eggs were laid daily. Eggs were predominantly white (Fig. 2a). Mean egg $(n=4)$ mass was $5.8 \pm 0.5 \mathrm{~g}(5-6 \mathrm{~g})$ and size $24.5 \times$ $19.00 \pm 0.06-0 \mathrm{~mm}(24-19 \times 25-19 \mathrm{~mm})$. We observed two adults on nest 1 during incubation period. The incubation period was 16 days.

We monitored the development of two nestlings only in nest 1 beginning two days after hatching. Nestlings hatch with light pink skin, yellow gape and slightly dark bill tip. Hatchlings had black plumes on the head, alar, humeral, and caudal tracts, and closed eyes (Fig. 2b). After four days, the eyes are slightly open, and the feathers of the remiges and rectrices start to develop (Fig. 2c). Nestling mass reached a mean 20-25 g after only 3-4 days, 38 g on day 8 (Fig. 2d) and 48-42 g on day 12, the heaviest recorded of any nestling (Fig. 2e, 3a). Chicks fledged after day 15 (Fig. 2f). We banded the chicks in the nest (codes $\mathrm{H}-91425$ and $\mathrm{H}-91420$ ). The longest nestling period was 15 days (Fig. 3a) and chicks fledged at a mean mass of

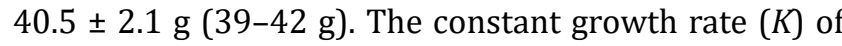
the nestlings was $0.31 \pm 0.07(0.26-0.42)$ with a growth asymptote of $46.3 \pm 14.2 \mathrm{~g}(42.7-52.3 \mathrm{~g})$.

We captured birds during all months and most young birds were caught October to March, with one in June (74 adults, 11 juveniles, Fig. 3b). Birds had brood patches from September to March ( $=9$; Fig. $3 b)$ and birds were molting flight feathers during January to July ( $\mathrm{n}=$ 33; Fig. 3b). Between 2002 and 2019 we banded 54 individuals: weight $42 \pm 7.4 \mathrm{~g}(25-64.3 ; \mathrm{n}=55) ;$ wing $100.7 \pm$ $11.1 \mathrm{~mm}(75-157, \mathrm{n}=55) ;$ tarsus $21.2 \pm 3.4 \mathrm{~mm}(15-29$ $\mathrm{mm}, \mathrm{n}=55)$; bill $28 \pm 5.5 \mathrm{~mm}(18-40 \mathrm{~mm}, \mathrm{n}=36)$; head size $49.8 \pm 1.6 \mathrm{~mm}(47.4-51.6 \mathrm{~mm}, \mathrm{n}=9)$; tail $86.3 \pm 8.5$ $\mathrm{mm}(65-109 \mathrm{~mm}, \mathrm{n}=51)$; total length $220.3 \pm 9.4 \mathrm{~mm}$ (198-240 $\mathrm{mm}, \mathrm{n}=38)$ and cloacal temperature $41 \pm 1.2$ ${ }^{\circ} \mathrm{C}\left(39.4-42.6^{\circ} \mathrm{C}, \mathrm{n}=6\right)$.
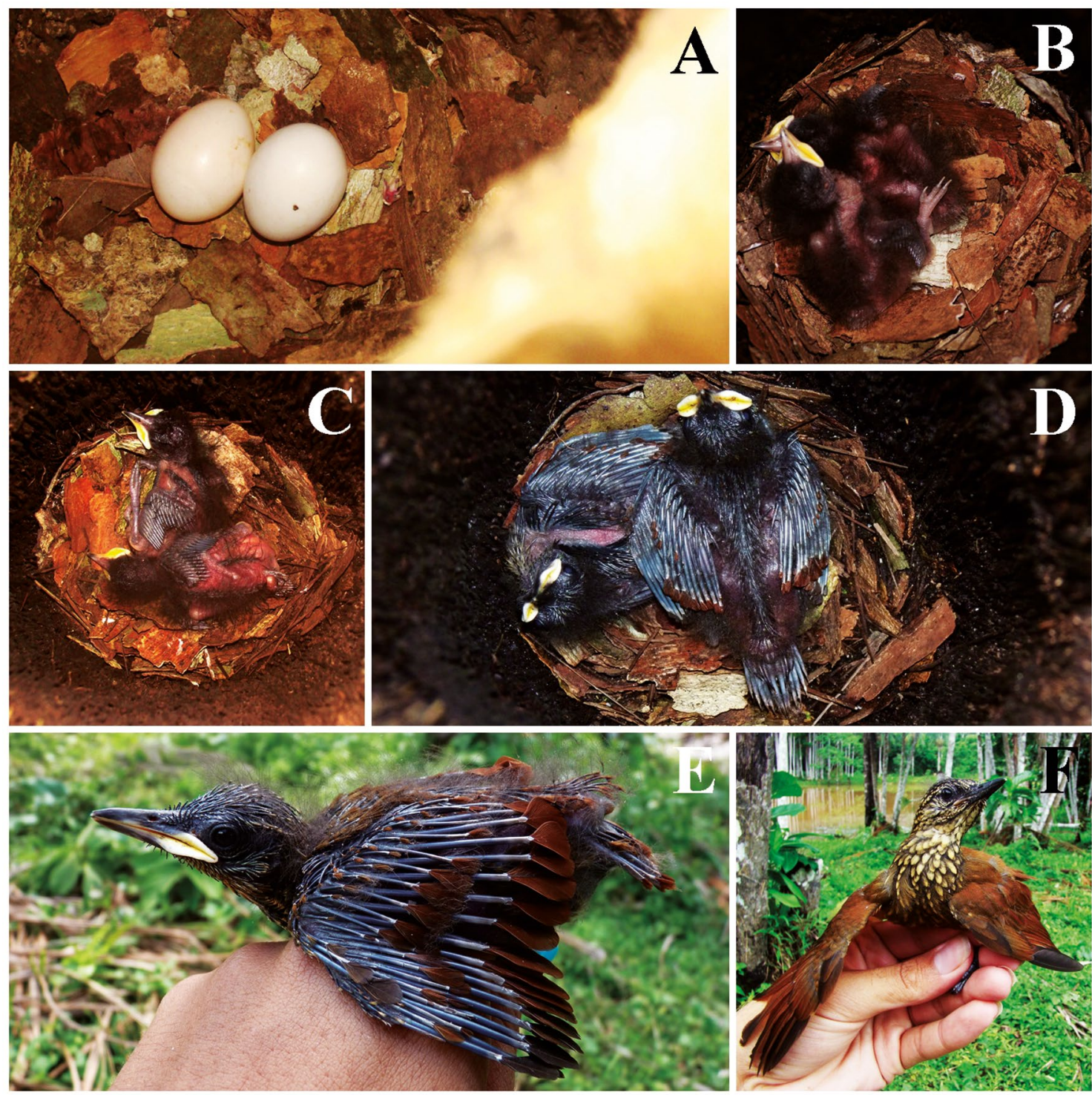

Figure 2. Development of Dendroplex picus peruvianus nestlings in a forest fragment in southwestern Amazonia in 2012 and 2013. (a) Detail of eggs and incubation chamber. (b) $2^{\text {nd }}$ day of monitoring. (c) $4^{\text {th }}$ day. (d) $8^{\text {th }}$ day. (e) $10^{\text {th }}$ day. (f) $15^{\text {th }}$ day. 


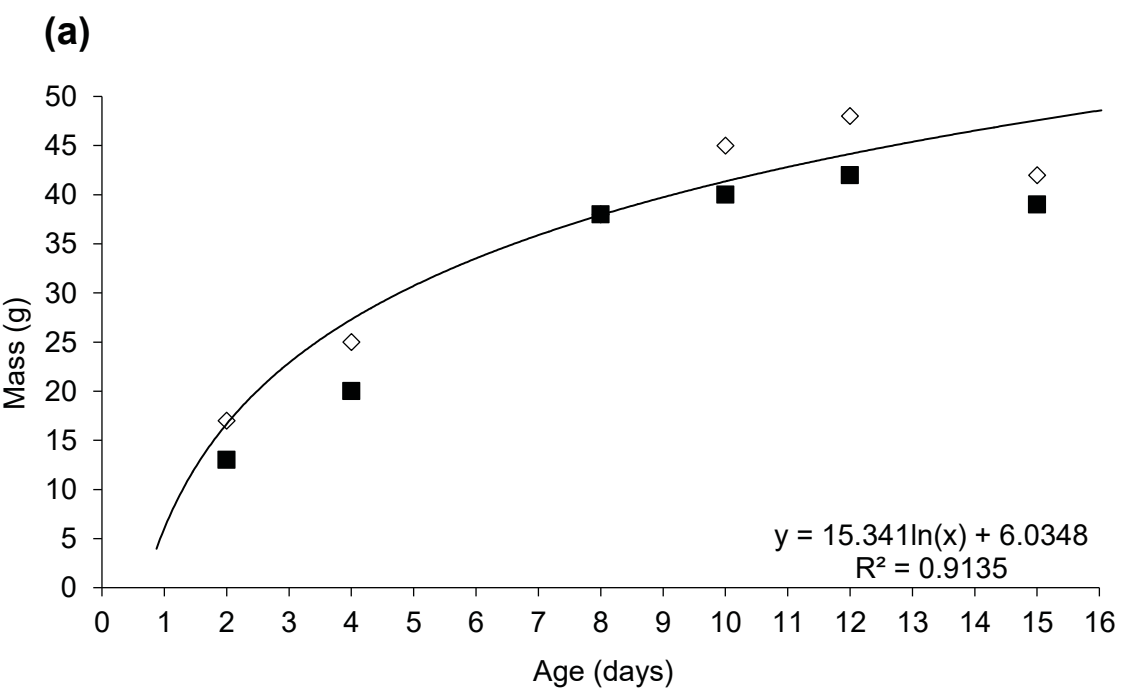

(b) $\quad \diamond$ Nestling 1 Nestling 2

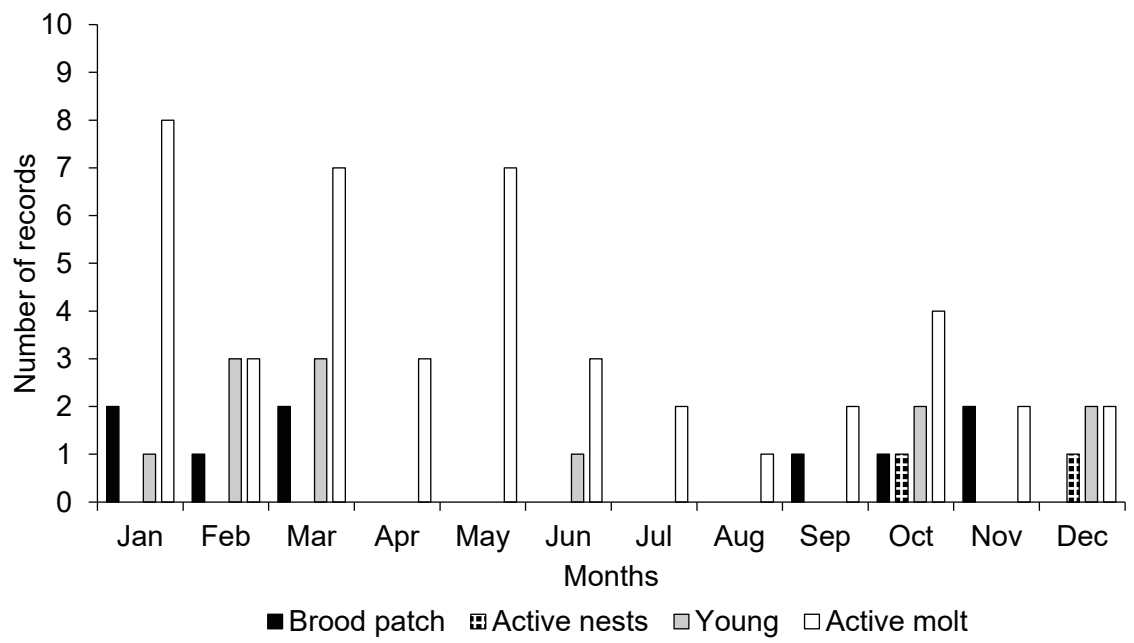

Figure 3. (a) Development and body mass of two nestlings monitored in a forest fragment in southwestern Amazonia in 2012. The logarithmic equation is based on the most developed chick. (b) Dendroplex picus peruvianus trapped in 1999-2002, 2004-2006 and 2009-2019, and active nests 2012 and 2013. Re-traps are not shown.

We made a total of 85 captures between 1999 and 2019,18 of which involved re-traps, five of which $(27.7 \%)$ more than once. We recorded a longest minimum longevity for individual G-34976 banded as an adult on January 2010 and last re-trapped on January 2018 (eight years after banding). The second longest-lived individual was G-91705 (four years). Two other longest-lived individuals were G-105899 (three years), G-39925 (three years). We re-trapped the individuals G-14455, G-91756, G-91872 all after two years and G91900, G-14489, G-35000, G-105891 after one year. The other seven individuals at intervals of $<1$ year.

\section{Discussion}

In ZP, D. picus breed in open areas with palms plantations with human activity, like other woodcreepers in Costa Rica (Skutch 1996) and southeastern Brazil (Oniki and Willis 2001). Contrary to south eastern Brazil (Santos et al. 2019) where D. picus is more sensible, the forested surrounding the nesting site in the ZP offers a secure environment for the species survival. In this stu- dy, all nesting characteristics were quite similar to those described for a different subspecies in Suriname and Venezuela (Hellebrekers 1942, Majewska \& Oteyza 2013). Regarding the growth rate of nestlings, ours are only the second calculations for D. picus. Nestling growth rate in this study was also similar to the only other estimates for the species, in Venezuela (D. p. picus, Majewska \& Oteyza 2013). Growth rate was also lower than those calculated for others Passeriformes at the same study site (Guilherme \& Lima 2019, Lima \& Guilherme 2020).

Dendroplex picus tends to breed preferentially at the onset of, and during, the rainy season (Haverschmidt \& Mees 1994, Oniki \& Willis 2001, Sanaiotti \& Cintra 2001, Majewska \& Oteyza 2013, Ingels \& Giraud-Audine 2013). In ZP, its nests in transition from the dry to the rainy season (September), extending on through the rainiest months of the year, continuing throughout the rainy season (until March) in Acre (Duarte 2006). At the beginning of the rainy season, D. picus benefits from an abundant supply of insects (Rodrigues 1992) to feed its 
young, mainly Coleoptera and Lepidoptera larvas like reported to Dendrocincla turdina and Dendrocolaptes platyrostris in Argentina (Cockle \& Bodrati 2009, Bodrati et al. 2018). In the western Amazon, insects may occur in greater abundance during the transition between the dry and rainy seasons than at other times of the year, as well as in tropical forests (Penny et al. 1978, Frith \& Frith 1985). Overlap moulting and breeding was observed for Glyphorhynchus spirurus in Amazonian Ecuador (Darrah \& Smith 2017) and for others dendrocolaptids in central Amazonia (Johnson et al. 2012) mainly in the dry season.

Overall mean body mass for the species is consistent with other studies (Oniki 1978, Silva et al. 1990, Marantz et al. 2020). Wing, bill, tail, and tarsus were all similar to those reported in southwestern Peruvian, Brazilian and Bolivian Amazonia (Hellmayr 1910, Zimmer 1934, Pinto \& Camargo 1954). The size of the head, cloacal temperatures and longevity data had not previously been reported for D. picus. Regarding the cloacal temperature data, ours are similar to seven woodcreepers species in northern Brazil (Oniki 1974). The variation in our minimum longevity records is consistent with those available for Dendrocincla fuliginosa and Sittasomus griseicapillus (7-10.5 years old) in Trinidad and Venezuela (Snow \& Lill 1974, Lentino et al. 2003).

\section{Literature cited}

Bodrati A, Cockle KL, Di Sallo FG. 2018. Nesting and natural history of the Plain winged Woodcreeper (Dendrocincla turdina): foraging associations and uniparental care. The Wilson Journal of Ornithology. 130(3): 696-707. https://doi.org/10.1676/17-076.1

Cockle KL, Bodrati AA. 2009. Nesting of the Planalto woodcreeper (Dendrocolaptes platyrostris). The Wilson Journal of Ornithology. 121(4): 789-795. https://doi. org/10.1676/08-107.1

Darrah AJ, Smith KG. 2017. Notes on display behavior, breeding, and fledgling care of the Wedge-billed Woodcreeper (Glyphorynchus spirurus) in Eastern Ecuador. The Wilson Journal of Ornithology. 129(2): 382-386. https://doi.org/10.1676/16-048.1

Duarte AF. 2006. Aspectos da climatologia do Acre, Brasil, com base no intervalo 1971-2000. Revista Brasileira de Meteorologia. 21(3): 308-317.

Frith CB, Frith DW. 1985. Seasonality of insect abundance in an Australian upland tropical rainforest. Austral Journal of Ecology. 10: 237-248.

Guilherme E. 2001. Comunidade de Aves do Campus e Parque Zoobotânico da Universidade Federal do Acre, Brasil. Tangara. 1(2): 57-73.

Guilherme E. 2016. Aves do Acre. Ed. Edufac (Editora da Universidade Federal do Acre), Rio Branco. 897 p.

Guilherme E, Lima JM. 2019. An update on the breeding biology and biometry of Hauxwell's Thrush (Turdus hauxwelii) from lowland southwestern Brazilian Amazon. Ornitología Neotropical. 30(4): 232-239.

Haverschmidt F, Mees GF. 1994. Birds of Surinam. Second Edition. Vaco N.V., Paramaribo, 579p.

Hellebrekers WPhJ. 1942. Revision of the Penard Oölogical collection from Surinam. Zoologische Mededeelingen. 24: $240-275$
Hellmayr CE. 1910. The birds of the Rio Madeira. Novitates Zoologicae, 17: 257-428.

Ingels J, Giraud-Audine M. 2013. Observations on nesting Straight-billed Woodcreepers Dendroplex picus (Furnariidae: Dendrocolaptinae) in French Guiana. Revista Brasileira de Ornitologia. 21(3): 157-161.

Johnson EI, Wolfe JD, Ryder TB, Pyle P. 2011. Modifications to a molt-based ageing system proposed by Wolfe et al. (2010). Journal of Field Ornithology. 82(4): 422-424. https://doi.org/10.2307/41409793

Johnson EI, Stouffer PC, Bierregaard RO. 2012. The phenology of molting, breeding and their overlap in central Amazonian birds. Journal of Avian Biology. 43: 141-154. https://doi.org/10.1111/j.1600-048X.2011.05574.x

Lentino ML, Bonaccorso E, García MA, Fernández EA, Rivero R, Portas C. 2003. Longevity records of wild birds in the Henri Pittier National Park, Venezuela. Ornitología Neotropical. 14: 545-548.

Lima J, Guilherme E. 2020. Breeding biology and biometrics of Silver-beaked Tanager Ramphocelus carbo connectens in south-west Brazilian Amazonia. Bulletin of the British Ornithologists' Club. 140(2): 170-181. https://doi.org/10.25226/bboc.v140i2.2020.a8

Majewska AA, Oteyza JC. 2013. Breeding biology of the Straightbilled Woodcreeper. The Wilson Journal of Ornithology. 125(1): 150-158. http://dx.doi.org/10.1676/10149.1

Marantz CA, Aleixo A, Bevier LR, Patten MA, de Juana E. 2020. Straight-billed Woodcreeper (Dendroplex picus), version 1.0. In: Birds of the World (del Hoyo J, Elliott A, Sargatal J, Christie DA, de Juana E. (Ed.). Cornell Lab of Ornithology, Ithaca, NY, USA.

Oniki Y. 1974. Some temperatures of birds of Belém, Brazil. Acta Amazonica. 4(3): 63-68. https://doi. org/10.1590/1809-43921974043063.

Oniki Y. 1978. Weights, digestive tracts and gonadal conditions of some amazonian birds. Revista Brasileira de Biologia. 38(3): 679-681.

Oniki Y, Willis EO. 1983. A study of breeding birds of the Belém area, Brazil: III. Trogonidae to Furnariidae. Ciência e Cultura. 35(9): 1320-1324.

Oniki Y, Willis EO. 2001. A contagem do número de dias para a incubação e da criação de jovens altriciais no ninho: a importância da padronização. Atualidades Ornitológicas. 100(2): 2.

Oniki Y, Willis EO. 2001. On a nest of the Planalto Woodcreeper, Dendrocolaptes platyrostris, with taxonomic and conservation notes. The Wilson Bulletin. 113(2): 231-233. https://doi. org/10.1676/0043-5643(2001)113[0231:OANOTP]2.0.CO;2

Penny ND, Arias JR, Schubart HOR. 1978. Tendências populacionais da fauna de coleópteros do solo sob floresta de terra firme na Amazônia. Acta Amazonica. 8(2): 259-265. https://doi.org/10.1590/180943921978082259.

Pinto OMO, Camargo EA. 1954. Resultados ornitológicos de uma expedição ao território do Acre pelo Departamento de Zoologia. Papéis Avulsos do Departamento de Zoologia, São Paulo. 11(23): 371-418.

R Development Core Team. 2018. R: A language and environment for statistical computing. Vienna: R Foundation for Statistical Computing. 
Redfern CPF. 2010. Brood-patch development and female body mass in passerines. Ringing \& Migration 25: 33-41. https://doi.org/10.1080/03078698.2010.9674412

Ricklefs RE. 1967. A graphical method of fitting equations to growth curves. Ecology. 48(6): 978-983. https://doi. org $/ 10.2307 / 1934545$

Rodrigues JMG. 1992. Abundância e distribuição vertical de coleópteros do solo em capoeira de terra firme na região de Manaus - AM, Brasil. Acta Amazonica. 22(3): 323-333. http://dx.doi.org/10.1590/180943921992223333

Sanaiotti TM, Cintra R. 2001. Breeding and migrating birds in an Amazonian savanna. Studies on Neotropical Fauna and Environment. 36(1): 23-32. https://doi. org/10.1076/snfe.36.1.23.8878

Santos GS, Ribeiro IC, Centoducatte LD, Mendes SL. 2019. Reprodução da avifauna e o processo de homogeneização em área verde planejada no sudeste da Mata Atlântica, Brasil. Neotropical Biology and Conservation. 14(1): 83-98. https://doi.org/doi: 10.3897/neotropical.14. e34838

Scholer MN, Merkord CL, Londoño GA, Jankowski JE. 2018. Minimum longevity estimates for some Neotropical landbirds of southeastern Peru. Wilson Journal of Ornithology. 130(3): 818-823. https://doi. org/10.1676/17-095.1

Schulenberg TS, Stotz DF, Lane DF, O’Neill JP, Parker III TA. 2010. Birds of Peru (Revised and Updated Edition). New Jersey: Princeton University Press, 664p.

Sibley DA. 2010. Aves: guía básica de identificación. Ed. Corbidi, Lima.

Skutch AF. 1996. Nesting of the Buff-throated Woodcreeper (Xiphorhynchus guttatus). The Auk. 113(1): 236-239. https://doi.org/10.2307/4088954

Snow DW, Lill A. 1974. Longevity records from some Neotropical land birds. Condor. 76(3): 262-267. https://doi. org $/ 10.2307 / 1366339$

Souza, J.B.; Guilherme, E.; Cornelius, C. 2020. Integrando fragmentos: Uma proposta de conectividade para duas áreas verdes urbanas do município de Rio Branco. Cap 06. Pp. 85-96. In: Pereira HS, Mariosa PH. (Orgs.). Riscos climáticos e perspectivas ambientais na Amazônia. Editora Appris. Curitiba, PR.

Zimmer JT. 1934. Studies of Peruvian birds. XIV Notes on the genera Dendrocolaptes, Hylexetastes, Xiphocolaptes, Dendroplex, and Lepidocolaptes. American Museum Novitates. 10: 1-26.
Agradecimientos / Acknowledgments:

To CNPq for providing JL with an undergraduate research stipend. To all members of the UFAC ornithology laboratory for support during field work. To Marcos Silveira and Evandro Ferreira for the identification of the plant support. To CEMAVE for providing the bands used in project 1099.

Conflicto de intereses / Competing interests:

No potential conflict of interest was reported by the authors.

Rol de los autores / Authors Roles:

$J L$ performed data collection, JL and EG wrote the work.

\section{Fuentes de financiamiento / Funding:}

This work was supported by Conselho Nacional de Desenvolvimento Científico eTecnológico (CNPq) [800217/20136; 800249/20143].

\section{Aspectos éticos / legales; Ethics / legals:}

Observational information did not require permits specific. Authors declare that they did not violate or omit ethical or legal norms in this research. 